\title{
A PARAMETRIC STUDY ON CONTROL OF FLOW SEPARATION OVER AN AIRFOIL IN INCOMPRESSIBLE REGIME
}

\author{
LAKSHMANAN PRABHU* AND JONNALAGADDA SRINIVAS \\ Department of Mechanical Engineering, National Institute of Technology, \\ Rourkela, Odisha-769008, India. \\ *Corresponding author: prabhulakshmananr@gmail.com
}

(Received: 23 ${ }^{\text {rd }}$ Dec 2016; Accepted: 15 ${ }^{\text {th }}$ June 2017; Published on-line: $1^{\text {st }}$ June 2018)

https://doi.org/10.31436/iiumej.v19i1.784

\begin{abstract}
This paper presents the effects of airfoil geometry on flow separation behavior and obtains the transition patterns at a specific angle of attack. A strong adverse pressure gradient field is observed at the leading edge of the airfoil, and it results in a flow detachment. Leading edge flow separation is studied along with the variation of skin friction coefficient over the airfoil. Novelty in the approach is the development of a hybrid control scheme to delay the flow separation with blowing/suction of air (termed active control) over the airfoil together with the tapping of flow from the pressure side as in a classical passive control procedure. The active controller delays the flow separation, while the passive controller is used to reduce the drag coefficient significantly and increases the total performance of an airfoil. The effectiveness of these controls is examined by varying the control parameters including blowing/suction velocity, the position of the slot in terms of percentage of chord and size of the slot. All the numerical simulations are carried out using ANSYS-Fluent software. A surrogate model is also developed to predict the aerodynamic characteristics conveniently without much computational effort. The outcome of this study reveals that the blowing/suction velocity has a higher influence in delaying the flow separation.
\end{abstract}

ABSTRAK: Kertas ini membentangkan tentang kesan geometri aerofoil pada perubahan pemisah aliran udara dan memperoleh bentuk peralihan pada darjah yang tepat. Terdapat tekanan kuat yang tidak sesuai pada kawasan kecerunan di hujung hadapan permukaan aerofoil, dan ini menyebabkan aliran udara terpisah. Pemisah aliran udara pada hujung hadapan ini dikaji bersama koefisien geseran pada permukaan aerofoil. Pendekatan baru pada kaedah ini adalah berkaitan pembangunan skim kawalan hibrid bagi melengahkan aliran pemisah udara melalui tiupan/sedutan udara (kawalan aktif) ke atas aerofoil bersama ketukan pada aliran dari tepi tekanan seperti mana prosedur klasik kawalan pasif. Kawalan aktif ini melengahkan aliran pemisah udara, sebaliknya kawalan pasif telah digunakan bagi mengurangkan koefisien penangguhan dengan ketara dan menambahkan jumlah prestasi aerofoil. Keberhasilan kawalan-kawalan ini dikaji dengan mengubah parameter kawalan termasuk kelajuan tiupan/sedutan udara, posisi slot berdasarkan peratusan garis temu dan saiz slot. Semua simulasi-simulasi numerikal ini dijalankan menggunakan perisian Ansys-Fluent. Model pengganti turut dibangunkan untuk menjangka ciri-ciri aero-dinamik dengan mudah tanpa usaha pengiraan yang banyak. Keputusan kajian ini mendedahkan tentang kelajuan tiupan/sedutan udara berpengaruh besar dalam melambatkan pemisahan aliran udara.

KEYWORDS: flow separation; aerodynamic characteristics; hybrid control; boundary layer; skin-friction coefficient 


\section{INTRODUCTION}

Airfoil sections are commonly found in several applications including the blades of turbo-machinery, wind turbines, aircraft wings, etc. Flow fields around airfoil sections have a significant influence on the overall aerodynamic characteristics. In fact, the fluid flow over the surface will become stagnant due to the viscous effect between the airfoil surface and the fluid under a no-slip boundary condition. As the flow passes downstream of the airfoil, where the motion of the fluid particles is already retarded by the frictional effects, the further increase in pressure gradient leads to reduced velocity. Further, moving in downstream, the fluid particle comes to a stop and leads to a reverse flow, this phenomenon leads the flow to separate from the airfoil surface and a wake region downstream of the surface is formed $[1,2]$. The transition point in a flow from laminar to turbulent is identified using the coefficient of friction $\left(\mathrm{C}_{\mathrm{f}}\right)$, where it increases suddenly along the flow direction. Over the last two decades, several studies focused on the flowcontrol techniques and airfoil design modifications [3-6].

The flow separation can be delayed; by augmenting the flow over an airfoil using various passive and active control solutions such as airfoils with air impingement, slats, and flaps. Ghadimi et al. [7] studied the effect of altitude on parameters like transition point and flow separation. The influence of these parameters on the drag produced was also investigated. The introduction of waviness on the airfoil to delay the flow separation was reported by Favier et al. [8]. To study the effect of waviness in depth, Lin et al. [9] used sinusoidal waviness on a symmetrical airfoil in two types; one was waviness over the upper and lower surfaces and another one was with waviness on the trailing and leading edges. The bumpy surface at $80 \%$ of the chord of the airfoil also delayed the flow separation [10]. The mean Reynolds stresses, as a key parameter for flow separation over an airfoil, was found by performing a study on the geometrical effects over the transition point and the flow separation [11]. More recently, Belamadi et al. [12] studied the effect of the slot shape in passive control of airfoil aerodynamic characteristics, particularly the ratio of the width of the slot on suction and the pressure side of the airfoil. The vortex generator was used as a tool to enhance aerodynamic characteristics [13]. The passive controller works well enough to increase the stall angle with weight as a penalty and intricate design.

To overcome these difficulties, the micro-mechanical and fluid system is used as an active controller that increases the stability in unsteady conditions. The continuously distributed porous surface on the airfoil was used to control the flow separation by applying the suction pressure under the porous surface [14]. The parametric study of the controller is very important to know which parameter has more significance on the delay of the flow separation. The location and angle of the controller were the most important parameters of the controller design in delaying flow separation [15-17]. The synthetic jet is an active controller that adds momentum to the flow without adding mass to it. Gilarranz et al. [18] conducted an experimental investigation on a NACA-0015 airfoil to delay the flow separation and increase the performance of an airfoil using the synthetic jet actuation. The flow separation delay over an airfoil with synthetic jet actuation was carried out numerically using large eddy simulation (LES) by You and Moin [19] and the results were compared with the experimental work performed by Gilarranz et al. [18]. Tang et al. [20] used two synthetic jet arrays in $23 \%$ and $43 \%$ of the chord to delay the flow separation. The experimental results show the first array was more efficient compared to the second array. The active controller was employed with different air blowing, such as pulsed and harmonic, to study its significance on delaying the separation [21]. Then coflow jet (CFJ) was employed to enhance the aerodynamic parameters and to increase the 
stall angle [22]. Genc and Kaynak [23] controlled the laminar separation over an airfoil by using the blowing and suction through the hole along various locations on the chord. The result shows the smaller blowing and larger suction velocity ratio gives the better result irrespective of the position of the hole. The suction controller with multi-holes shows better aerodynamic performance against the single hole [24]. Skarolek and Karabelas [25] used a non-conventional active flow control scheme that results in excellent efficiency in aerodynamic characteristics before and after the flow separation. Here the slots were provided on both suction and pressure side at the trailing edge, that blows the air perpendicular to the chord. The ANSYS tool is used to check, how the system performs before going for the prototype. Ali and Ahmed [26] used Reynolds-Averaged Navier Stokes (RANS) based two equation turbulence model (k- $-\varepsilon$ ), and the grid generation was based on the body-fitted coordinate system to identify the separation point over an airfoil surface. Kuwahara and Surugadai [27] predicted the flow around the airfoil using the multi-directional finite difference method to solve the Navier-Stokes equation, which leads to a computation approach much wider.

Most of the above works were employed with either passive or active control techniques for flow separation. Recently, the hybrid control schemes have become more popular for their effectiveness in controlling flow separation. Unlike existing hybrid methods for control of flow separation, the present approach considers a continuous blowing/suction jet impingement along with a passive controller using a slot that taps the flow from the pressure side and releases it just before the trailing edge to enhance the aerodynamic characteristics. Initially, the conditions of flow separation are identified and the proposed concept of separation control is implemented on NACA 0015 airfoil, to know its effectiveness. During the controller design, effects of controlling parameters such as blowing/suction velocity, the position of the slot in the percentage of chord and size of the slot on the aerodynamic performance of airfoil are studied. Based on these studies, the surrogate models are developed based on two neural networks namely, general regression neural network (GRNN) and radial basis function (RBF) network to predict the aerodynamic characteristics more accurately and relatively faster with parameters of the controller as an input.

\section{METHODOLOGY}

\subsection{Hybrid Control Concept}

Active controllers use the continuous blowing/suction of air through a slot using the external sources. A passive controller is a technique that does not use any external aid and the slot extends from the pressure side of the airfoil to the suction side. The combination of both active and passive controllers is termed as the hybrid controller. The passive control slot size effect studied by Belamadi et al. [12] is used in combination with the nonconventional controller by Skarolek and Karabelas [25] in this work, but the blowing (passive) slot is placed only on the suction side, just ahead of the trailing edge as shown in Fig. 1.

The slot for the passive controller has a greater width on the pressure side and a lower width on the suction side. The slot position on the suction side is about three percent of the chord length from the trailing edge (T.E), and the width of the hole in terms of ratio of chord is $0.0133 \mathrm{~m}$. Figure 1 shows the airfoil with slots for the active and passive controller. 


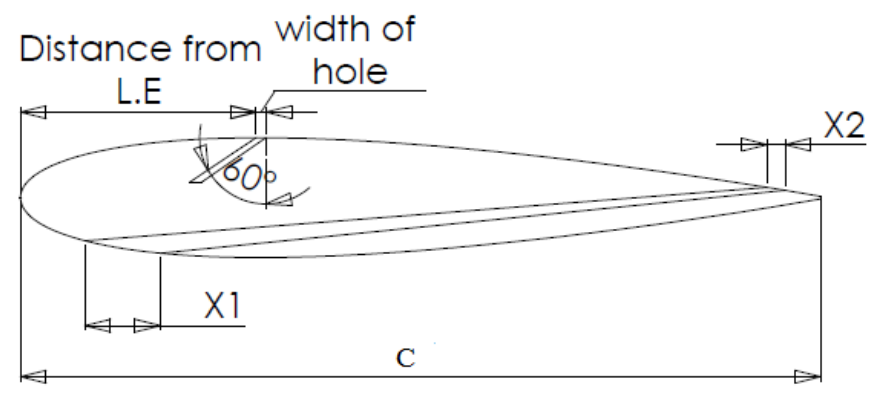

Fig. 1: Hybrid controller design in airfoil.

\subsection{Artificial Neural Networks}

An artificial neural network is designed based on the biological neural system and it is widely used as a surrogate model in many engineering applications. Of all neural networks $(\mathrm{NN})$, the three-layer RBF and its variants, like PNN, GRNN, CPN, etc., have become famous due to limited network parameters and reliability in giving output results. The $\mathrm{RBF}$ is one of the neural network tools [28] that is a feed-forward with three layers, one is input, the other is hidden or known as a radial basis layer, the last is the output layer. Figure 2 shows the block diagram of the RBF.

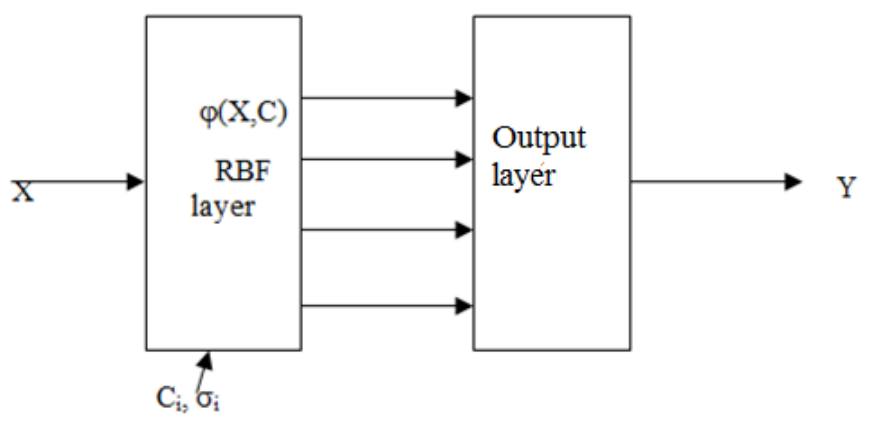

Fig. 2: RBF neural network structure.

The hidden layer comes with a non-linear RBF activation code. RBF represents a local effect and its range is identified by the center element and width. The output layer is the sum of the weighted outputs of the hidden layer defined below:

$$
\mathrm{Y}(\mathrm{X})=\mathrm{W} \varphi(\mathrm{X}, \mathrm{C})
$$

where $\mathrm{X}$ is input vector, $\mathrm{W}$ is connection weight, $\mathrm{C}$ is central vector, and $\varphi$ is radial basis function which in most of the cases is Gauss function defined by following equation:

$$
\varphi(X, C)=G(\|X-C\|)=\exp \left(-\frac{1}{\sigma^{2}}\|X-C\|^{2}\right)
$$

where $\sigma$ represents the width. The RBF is trained using the estimation of parameters such as centers, widths of RBF, and connection weights.

\subsection{General Regression Neural Networks}

The GRNN is a combination of radial basis layer and a special linear layer [29]. GRNN comes under probabilistic neural networks, and it is a simple one-pass algorithm with a parallel structure that requires only a few training sets compared to back propagation neural networks (BPNN). In addition, parameters such as the optimum 
number of neurons, learning rate, and momentum are not required, as in BPNN. The biggest advantage is its ability to converge with few training sets and a smooth transition is observed from one value to another. GRNN comes with four layers: the input, pattern, summation, and output layers as shown in Fig. 3.

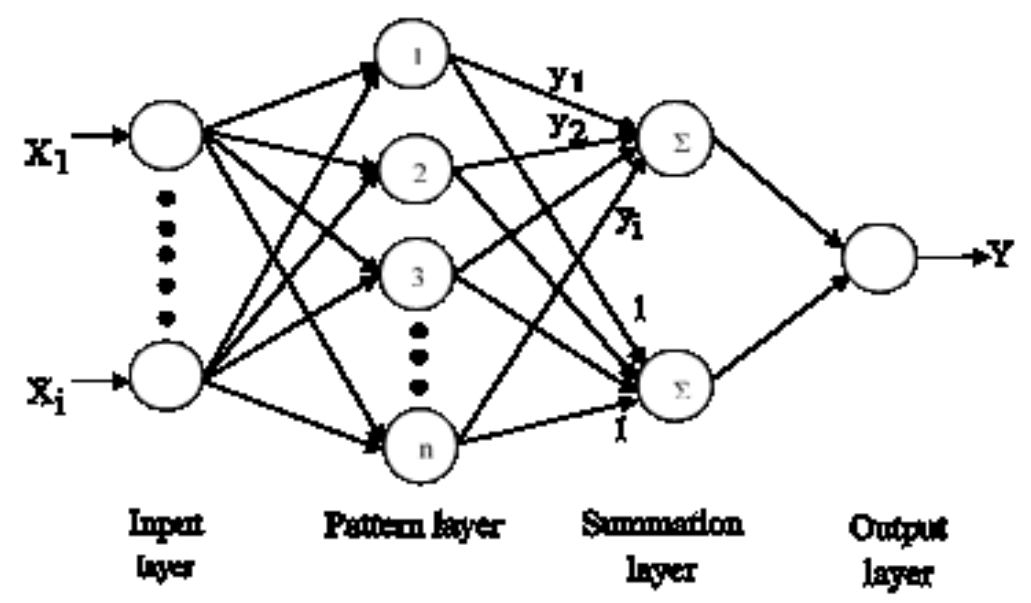

Fig. 3: GRNN structure.

The input layer consists of the same number as the features of a model and it will be passed to the pattern layer. Next is the summation layer, consisting of two units where all nodes in the third layer are connected to both units. Finally, the output layer is the quotient of two units in summation layer, which is given below:

$$
\mathrm{Y}(\mathrm{X})=\frac{\sum_{\mathrm{i}=1}^{\mathrm{n}} \mathrm{y}_{\mathrm{i}} \exp \left(-\frac{\mathrm{d}_{\mathrm{i}}^{2}}{2 \sigma^{2}}\right)}{\sum_{\mathrm{i}=1}^{\mathrm{n}} \exp \left(-\frac{\mathrm{d}_{\mathrm{i}}^{2}}{2 \sigma^{2}}\right)}
$$

where $y_{i}$ is the connection weight between the first summation node and the $i^{\text {th }}$ node of the pattern layer, $n$ is number of data samples, $d_{i}^{2}=\left(X-X^{i}\right)^{T}\left(X-X^{i}\right)$ is Euclidean distance between the weights and the input vector, and $\sigma$ is the spread parameter.

Figure 4 shows the flowchart of the methodology and it starts with the selection of an airfoil to identify the flow separation point, which in turn helps to identify the parameters such as slot size, location along the chord, and blowing/suction velocity (active controller). As a next step, aerodynamic characteristics are calculated using both active and hybrid controllers to find their effectiveness on the control of flow separation. Then comes the training of surrogate models and its performance is compared with ANSYS Fluent.

\section{NUMERICAL SIMULATION}

The baseline airfoil model employed in this work is NACA 0015 with a chord of $0.375 \mathrm{~m}$ with a free stream velocity of $35 \mathrm{~m} / \mathrm{s}$, leading to a Reynolds number of $(\mathrm{Re})=8.96 \mathrm{e} 5$ and a turbulence intensity of 0.3 percent. The experimental data [18] is used to validate the results of the numerical simulation without controller. 2-D simulation is efficient in the studies where large amounts of simulation cases are needed for an investigation of the effect of aerodynamic parameters. All the flow studies are carried out using ANSYS Fluent. The physical two-dimensional model in C-type domain with the 
radius of $10 \mathrm{c}$ and width of $12 \mathrm{c}$ is shown in Fig.5 and flow considered is incompressible and subsonic in nature.

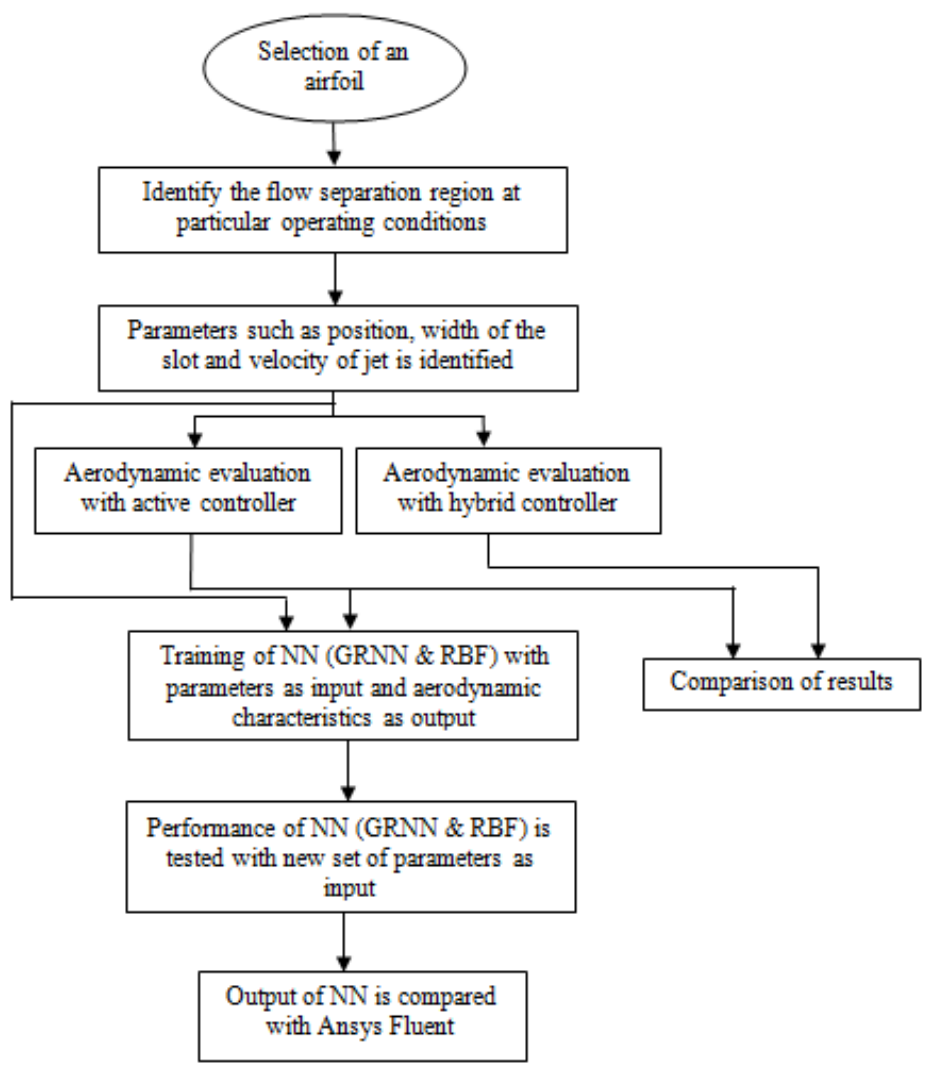

Fig. 4: Flowchart of the methodology.

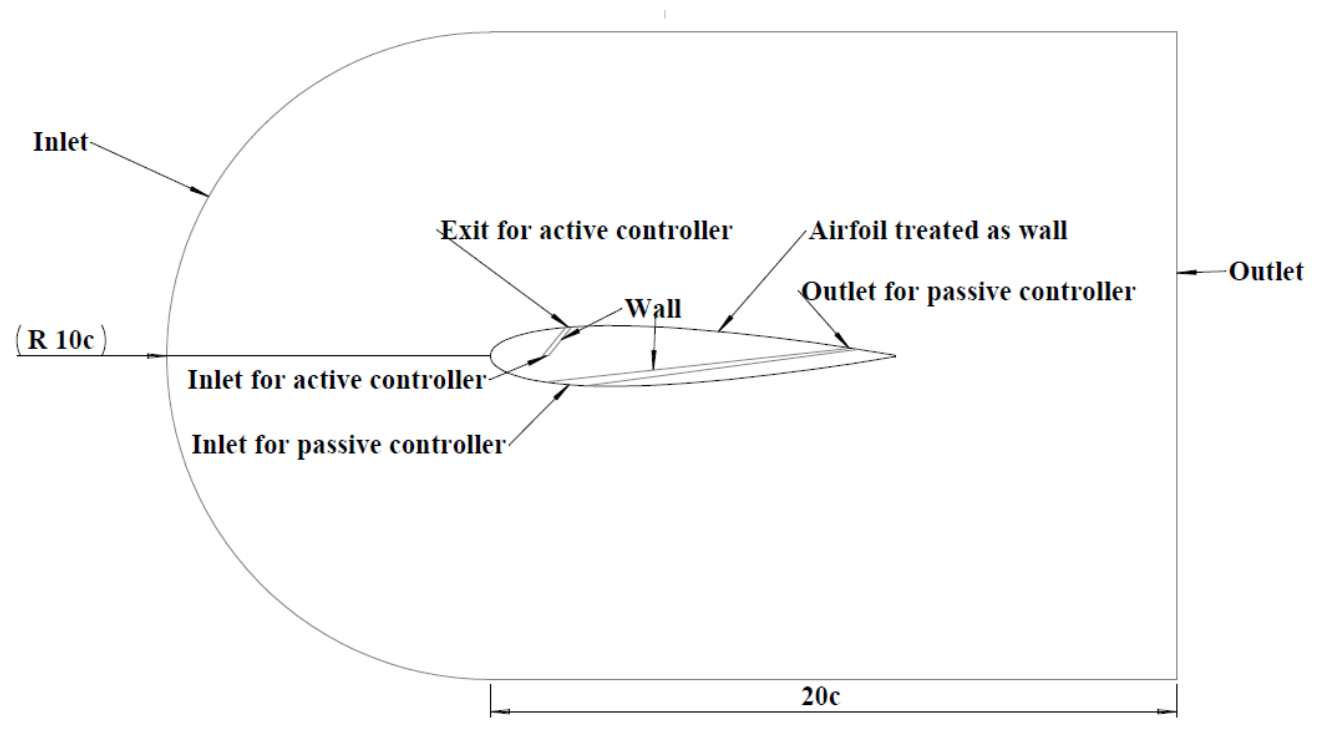

Fig. 5: CFD physical modeling.

When the flow passes around the airfoil, separation begins in absence of the controller at a certain angle of attack and free-stream velocity. When the controller comes to effect along with the freestream velocity, the air impingement or suction will take place through the inlet for the active controller, and the air will enter through the passive 
controller inlet and exit via the outlet for the passive controller. The boundary conditions used in the simulation are as follows:

1) The simulation is performed in the standard atmospheric conditions.

2) The inlet and outlet are treated as velocity inlet and pressure outlet respectively.

3) The airfoil is treated as the wall with no slip boundary conditions.

4) The inlet for the active controller is considered to be the velocity inlet (blowing/suction of air).

5) The pressure side air will pass through the inlet for the passive controller and exit through the outlet of the passive controller.

The general two-dimensional forms of continuity and momentum equations for an incompressible flow are described as;

$$
\begin{aligned}
& \frac{\partial \mathrm{u}}{\partial \mathrm{x}}+\frac{\partial \mathrm{v}}{\partial \mathrm{y}}=0 \\
& \frac{\partial \mathrm{u}}{\partial \mathrm{t}}+\mathrm{u} \frac{\partial \mathrm{u}}{\partial \mathrm{x}}+\mathrm{v} \frac{\partial \mathrm{u}}{\partial \mathrm{y}}=-\frac{1}{\rho} \frac{\partial \mathrm{p}}{\partial \mathrm{x}}+v \frac{\partial^{2} \mathrm{u}}{\partial \mathrm{x}^{2}}+v \frac{\partial^{2} \mathrm{u}}{\partial \mathrm{y}^{2}} \\
& \frac{\partial \mathrm{v}}{\partial \mathrm{t}}+\mathrm{u} \frac{\partial \mathrm{v}}{\partial \mathrm{x}}+\mathrm{v} \frac{\partial \mathrm{v}}{\partial \mathrm{y}}=-\frac{1}{\rho} \frac{\partial \mathrm{p}}{\partial \mathrm{y}}+v \frac{\partial^{2} \mathrm{v}}{\partial \mathrm{x}^{2}}+v \frac{\partial^{2} \mathrm{v}}{\partial \mathrm{y}^{2}}
\end{aligned}
$$

where $\mathrm{u}, \mathrm{v}$ are velocity components, and $\mathrm{p}, \mathrm{v}$, and $\rho$ are pressure, kinematic viscosity, and density, respectively. The RANS based turbulence model is used in this numerical simulation. The transitional k-kl- $\omega$ is a RANS-based model, proposed by Walters and Cokljat [30] and this model is developed based on a turbulence $\mathrm{k}-\omega$ model. The $\mathrm{k}-\omega$ is a two-equation model in which the equations are used to identify the turbulent kinetic energy and the specific dissipation energy [30]. In two-equation models, the physics of transition of flow is missing. To overcome this, a k-kl- $\omega$ transition model was developed [30]. It predicts the development of a boundary layer and onset of the transition from laminar to turbulent. The model uses a three-equation eddy viscosity type: the transport equation for turbulent kinetic energy $\left(\mathrm{k}_{\mathrm{T}}\right)$, laminar kinetic energy $\left(\mathrm{k}_{\mathrm{L}}\right)$ and the inverse turbulent time scale $(\omega)$ as follows [30]:

$$
\begin{aligned}
& \frac{\mathrm{Dk}_{\mathrm{T}}}{\mathrm{Dt}}=\mathrm{P}_{\mathrm{k}_{\mathrm{T}}}+\mathrm{R}+\mathrm{R}_{\mathrm{NAT}}-\omega \mathrm{k}_{\mathrm{T}}-\mathrm{D}_{\mathrm{T}}+\frac{\partial}{\partial \mathrm{x}_{\mathrm{j}}}\left[\left(v+\frac{\alpha_{\mathrm{T}}}{\sigma_{\mathrm{k}}}\right) \frac{\partial \mathrm{k}_{\mathrm{T}}}{\partial \mathrm{x}_{\mathrm{j}}}\right] \\
& \frac{\mathrm{Dk} \mathrm{L}_{\mathrm{L}}}{\mathrm{Dt}}=\mathrm{P}_{\mathrm{k}_{\mathrm{L}}}-\mathrm{R}-\mathrm{R}_{\mathrm{NAT}}-\mathrm{D}_{\mathrm{T}}+\frac{\partial}{\partial \mathrm{x}_{\mathrm{j}}}\left[v \frac{\partial \mathrm{k}_{\mathrm{T}}}{\partial \mathrm{x}_{\mathrm{j}}}\right] \\
& \frac{\mathrm{D}_{\omega}}{\mathrm{D}_{\mathrm{t}}}=\mathrm{C}_{\omega \mathrm{\omega}} \frac{\omega}{\mathrm{k}_{\mathrm{T}}} \mathrm{P}_{\mathrm{k}_{\mathrm{T}}}+\left(\frac{\mathrm{C}_{\omega \mathrm{R}}}{\mathrm{f}_{\mathrm{W}}}-1\right) \frac{\omega}{\mathrm{k}_{\mathrm{T}}}\left(\mathrm{R}+\mathrm{R}_{\mathrm{NAT}}\right)-\mathrm{C}_{\omega 2} \omega^{2}+\mathrm{C}_{\omega 3} \mathrm{f}_{\omega} \alpha_{\mathrm{T}} \mathrm{f}_{\omega}^{2} \frac{\sqrt{\mathrm{k}_{\mathrm{T}}}}{\mathrm{d}^{3}}+\frac{\partial}{\partial_{\mathrm{x}_{\mathrm{j}}}}\left[\left(v+\frac{\alpha_{\mathrm{T}}}{\alpha_{\omega}}\right) \frac{\partial_{\omega}}{\partial_{\mathrm{x}_{\mathrm{j}}}}\right]
\end{aligned}
$$

The stringent modeling near the wall model (airfoil) has to be carried out to study the turbulent flow problems. The first cell height $(\Delta y)$ from the wall must be identified by the appropriate dimensionless $\mathrm{y}^{+}$value. The $\Delta \mathrm{y}=8.3 \mathrm{e}-06 \mathrm{~mm}$ for $\mathrm{y}^{+}=1$, and the enhanced wall treatment is used in this study. The residual convergence criterion is fixed to $10 \mathrm{e}-6$ to achieve reliable results. 
The meshing tool used is ICEM CFD, and the mesh type is a structured one with quadrilateral elements. The structured block, mesh, and magnified mesh over an airfoil are shown in Fig. 6.

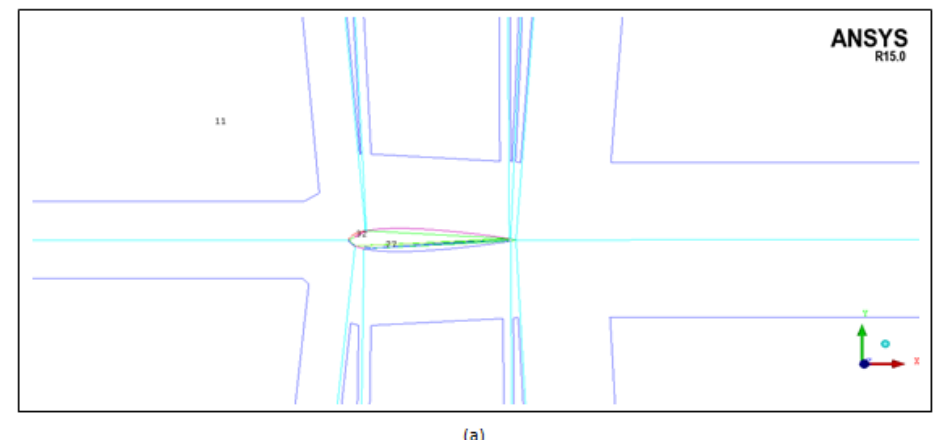

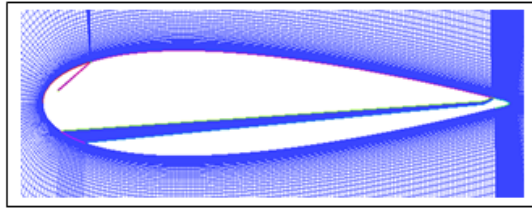

(b)

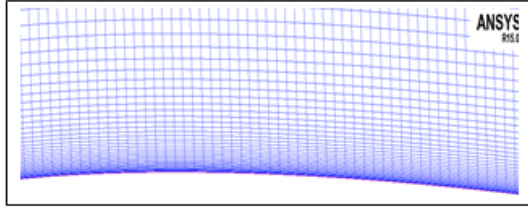

(c)

Fig. 6: (a) structured block, (b) mesh, and (c) magnified mesh over an airfoil.

To proceed further in the analysis, the grid independence is carried out by varying the number of mesh points $(\mathrm{M} 1=300, \mathrm{M} 2=400$, and $\mathrm{M} 3=500)$ over the airfoil and the respective aerodynamic characteristics at various AOA are shown in Fig 7. The lift coefficient by all mesh points is more or less similar, but the drag coefficient by M1 has a large deviation compared to the other two. M2 and M3 give the closer aerodynamic coefficients with less error; approximately $4 \%$. To reduce the computational time, M2 is selected for further numerical studies.

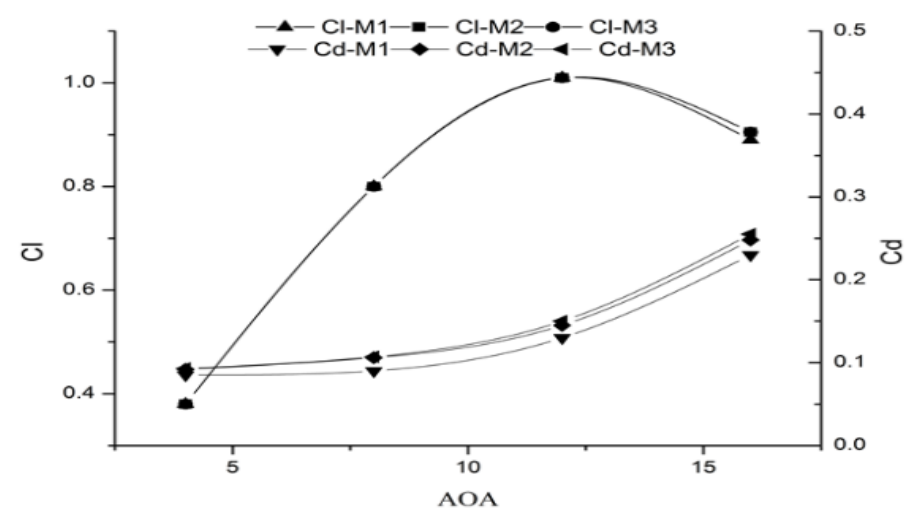

Fig. 7: Grid independence study.

The entire analysis is performed in a high performing computing machine in 16 nodes with a memory of $64 \mathrm{~GB}$ on an Intel processor of $2 \mathrm{GHz}$ speed. The average time taken for each simulation is around 128 minutes. Figure 8 shows the aerodynamic coefficients obtained from the numerical simulation in comparison with experimental data [18]. 


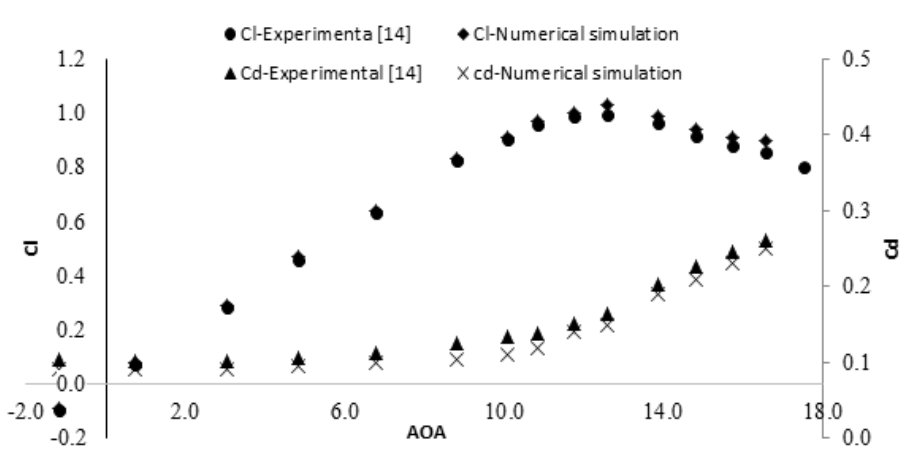

Fig. 8: Aerodynamic coefficients of NACA 0015 airfoil by CFD for uncontrolled case in comparison with experimental value [18].

From the earlier work [18] it was experimentally found that the stall occurs at approximately $12.6^{\circ}$ and a separation of flow takes place at $40 \%$ of the chord from the T.E. The flow separation starts at L.E over an airfoil at AOA $=16.6^{\circ}$ as shown in Fig. 9.

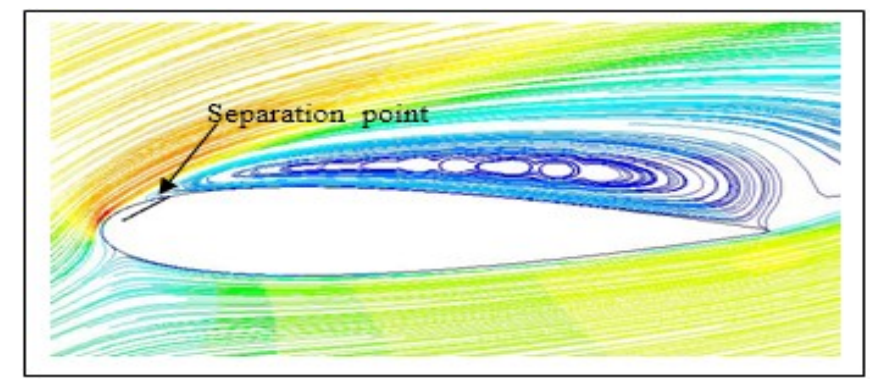

Fig. 9: Flow separation over an airfoil at $\mathrm{AOA}=16.6^{\circ}$.

The present study focuses on the suppression/delay of the flow separation over an airfoil at AOA of $16.6^{\circ}$. The residual and aerodynamic coefficients convergence graphs of uncontrolled flow over a NACA 0015 airfoil at an AOA $16.6^{\circ}$ are shown in Fig. 10 using numerical simulation and Table 1 displays the aerodynamic characteristics values in comparison with available experimental results [18].

Table 1: Aerodynamic characteristics at $\mathrm{AOA}=16.6^{\circ}$ uncontrolled case

\begin{tabular}{|c|c|c|}
\hline Aerodynamic characteristics & Present simulation & Experimental [14] \\
\hline $\mathrm{C}_{1}$ & 0.90 & 0.85 \\
\hline $\mathrm{C}_{\mathrm{d}}$ & 0.25 & 0.26 \\
\hline $\mathrm{L} / \mathrm{D}$ & 3.6 & 3.27 \\
\hline
\end{tabular}

\subsection{Parametric Study}

For the influence of parameters such as blowing velocity, and the position of the slot in the percentage of chord and size of the slot on the output factor, the aerodynamic characteristics are studied. Fig. 1 shows the airfoil NACA-0015 with a chord (c) of 0.375 $\mathrm{m}$. The Taguchi method is employed for three levels and three parameters, as given in Table 2 and then the $\mathrm{L}_{9}(3 * 3)$ orthogonal array is used to find the possible number of experiments. As the essential objective is to maximize the efficiency of the airfoil in terms 


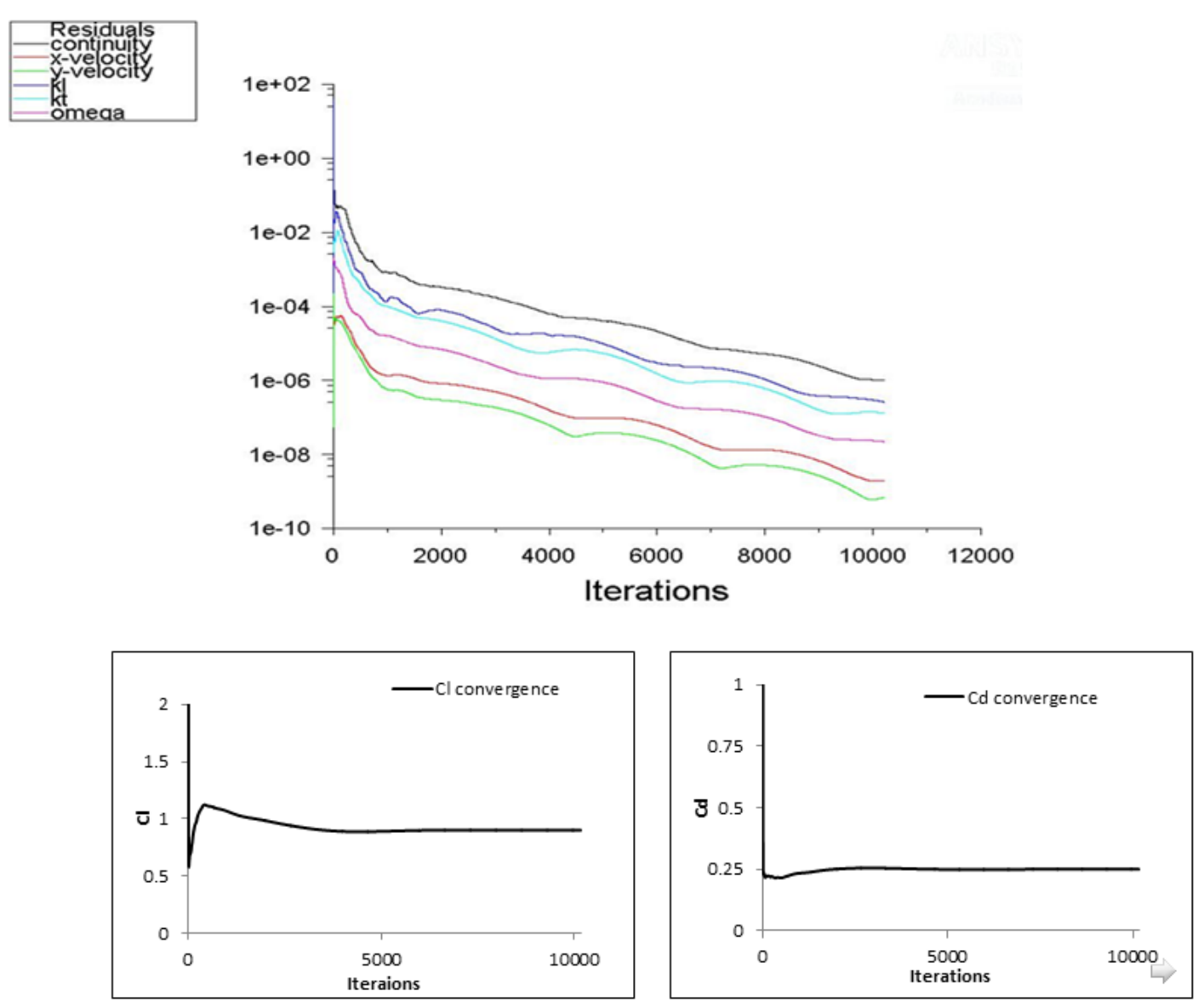

Fig. 10: Convergence graph of residual and aerodynamic coefficients at AOA $16.6^{\circ}$ for an uncontrolled case.

of aerodynamic characteristics, one has to predict the best level of each factor. Minitab 16 is used to carry out the Taguchi method and the aerodynamic characteristics of 9 combinations are predicted using CFD, then fed into Minitab to get the means graphs for analysis. The slot for the controller is placed at a different position along the chord with various width and blowing/suction velocities, as shown in Table 2.

Table 2: Parameters of the controller

\begin{tabular}{cccc}
\hline Level & $\begin{array}{c}\text { Blowing/suction velocity in } \\
{[\mathbf{m} / \mathbf{s}]}\end{array}$ & $\begin{array}{c}\text { Position of slot in \% of } \\
\mathbf{c}\end{array}$ & $\begin{array}{c}\text { Size of slot in } \\
{[\mathbf{m}]}\end{array}$ \\
\hline $\mathbf{1}$ & 17.5 & 10 & 0.0015 \\
$\mathbf{2}$ & 35 & 30 & 0.002 \\
$\mathbf{3}$ & 52.5 & 50 & 0.0025 \\
\hline
\end{tabular}

\subsection{Active Controller Effect}

From Fig. 9, it can be witnessed that for the control-off case, the flow separation starts below the $10 \%$ of chord from the L.E and the active controller used is to mitigate the flow separation over an airfoil by continuous blowing/suction of air tangentially over the suction side of the airfoil and as a result, it lead to an improvement of aerodynamic characteristic. In Fig. 11, pressure distribution over the baseline airfoil with active controller on cases, shows the rise in the peak on the suction side along with the increase 
of pressure on the pressure side when compared to the airfoil with a control-off case. It shows the active controller has a global effect over the suction side pressure distribution.

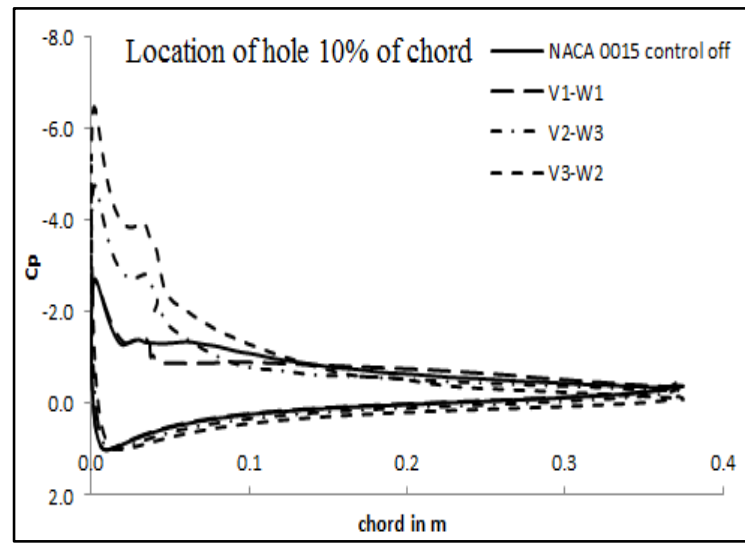

(a)

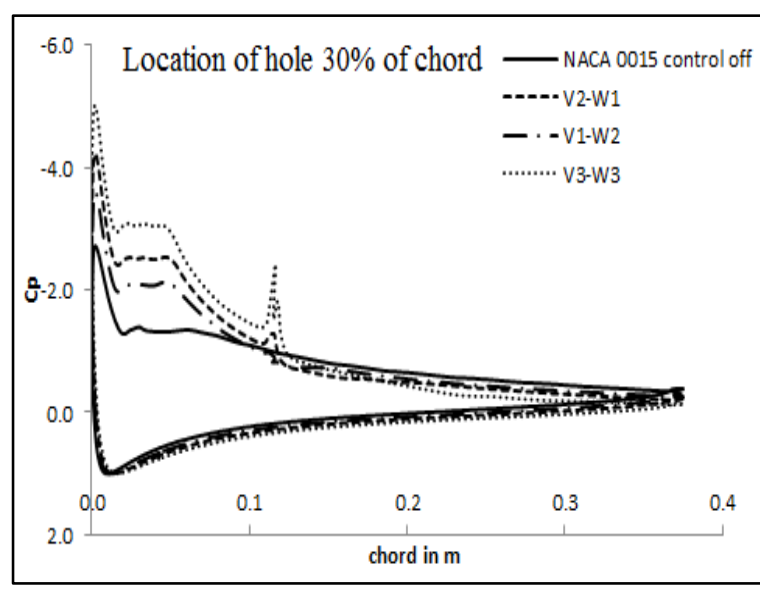

(b)

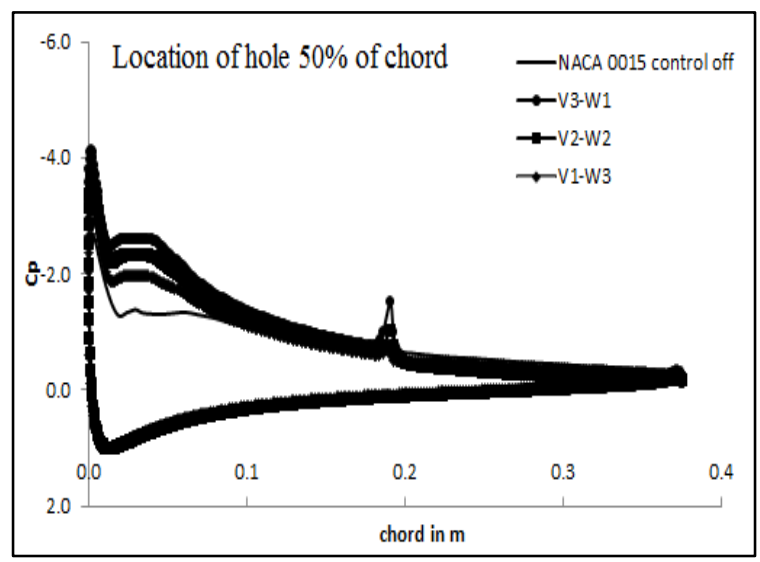

(c)

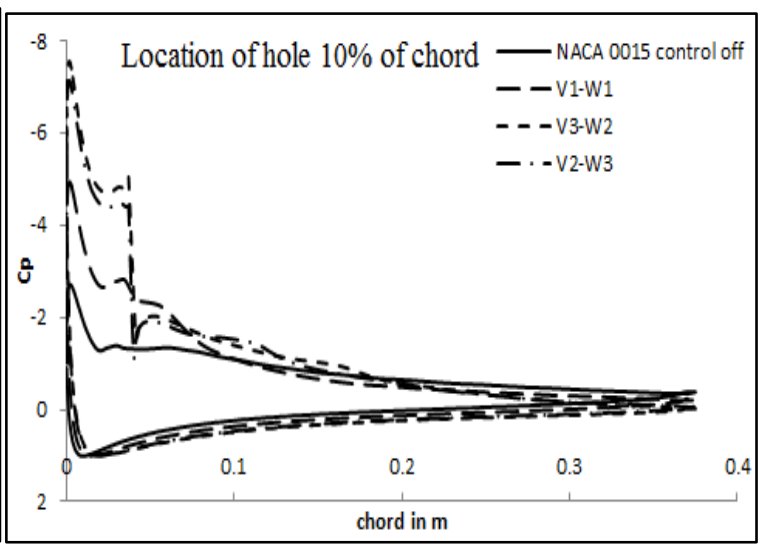

(d)

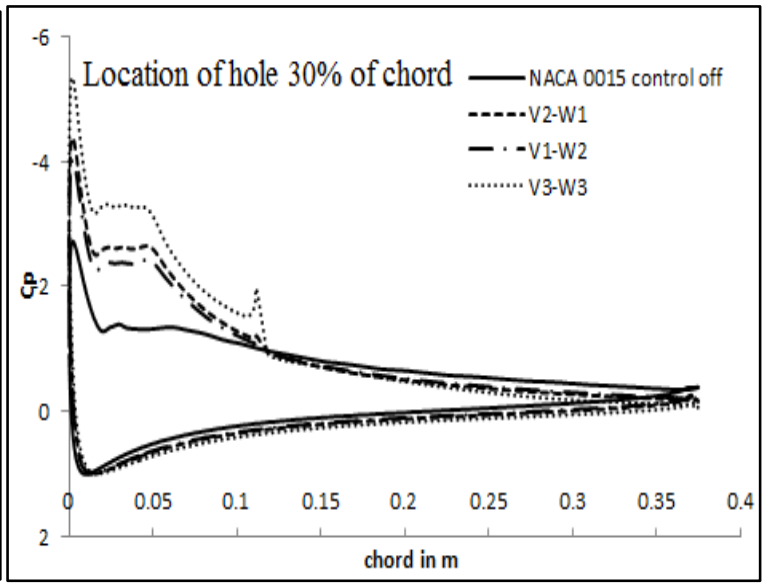

(e)

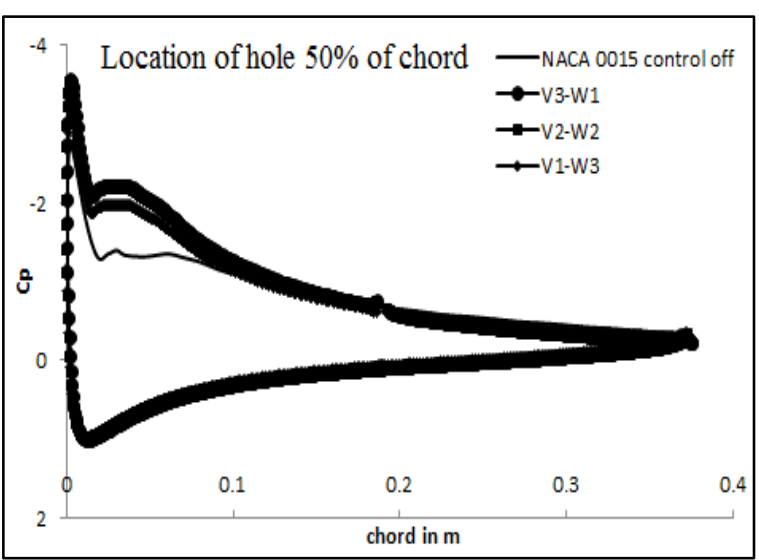

(d)

Fig. 11: Pressure distribution over a baseline airfoil NACA 0015 with active controller on and off cases, (a), (b), (c) are blowing and (d), (e), (f) are suction $(\mathrm{v} 1=17.5 \mathrm{~m} / \mathrm{s}, \mathrm{v} 2=35 \mathrm{~m} / \mathrm{s}, \mathrm{v} 3=52.5 \mathrm{~m} . / \mathrm{s}, \mathrm{w} 1=0.0015 \mathrm{~m}, \mathrm{w} 2=0.002$, and $\mathrm{w} 3=0.0025)$ 


\subsection{Hybrid Controller Effect}

The combination of the active and passive controller is employed in this work. Here the active controller is to mitigate the flow separation as mentioned earlier, but the work of the passive controller is to reduce the total drag instead of controlling the flow separation. Figure 12 shows the pressure coefficient over a baseline airfoil NACA 0015 with hybrid controller off and on cases. The flow over the suction side gets decelerated and the pressure starts rising on the upstream of the passive controller as the blowing of the air jet is carried out. The increase in the static pressure improves the $\mathrm{L} / \mathrm{D}$ ratio by reducing the drag value.

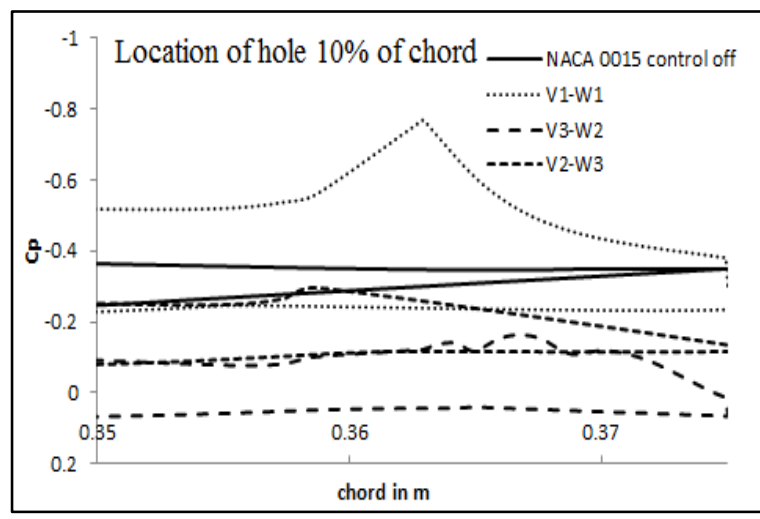

(a)

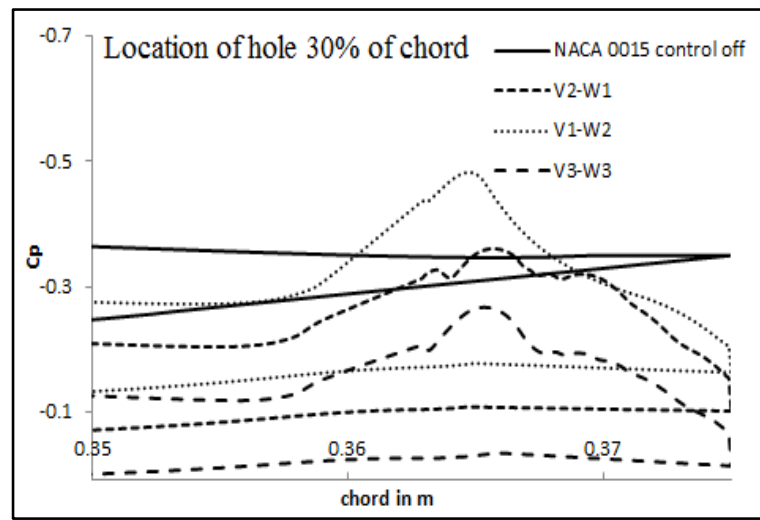

(b)

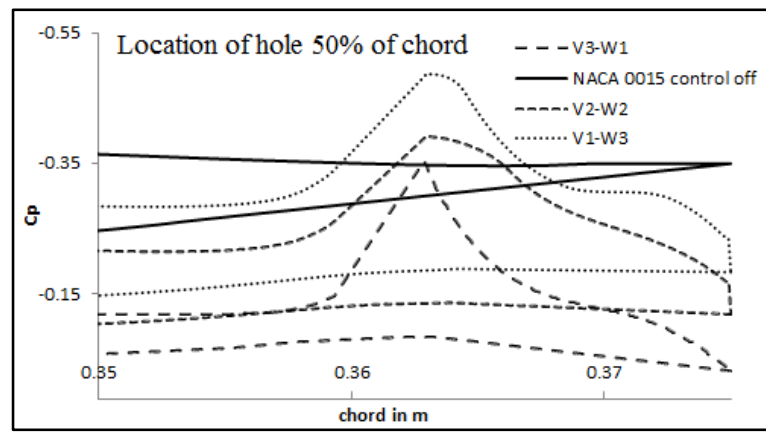

(c)

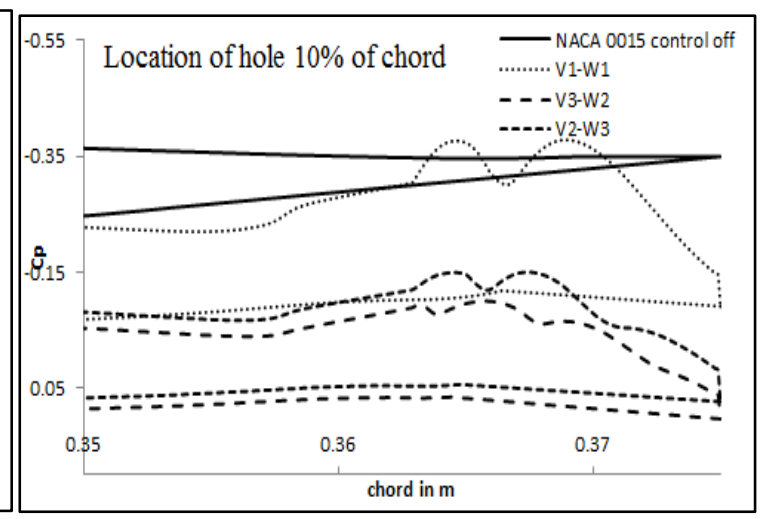

(d)

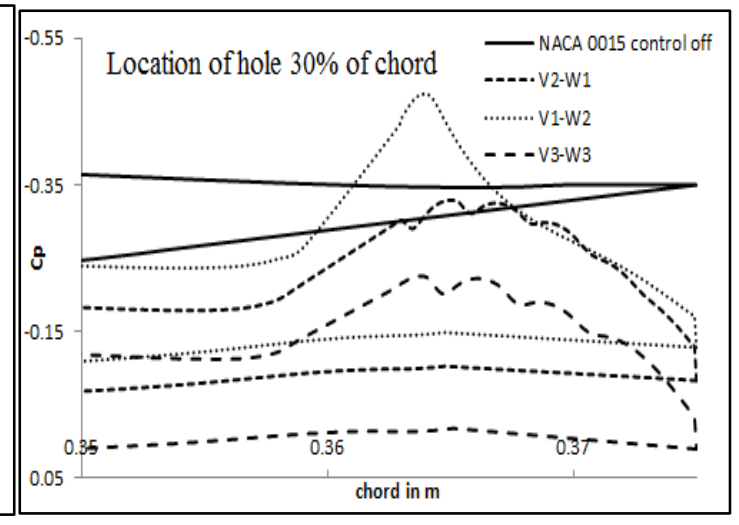

(e)

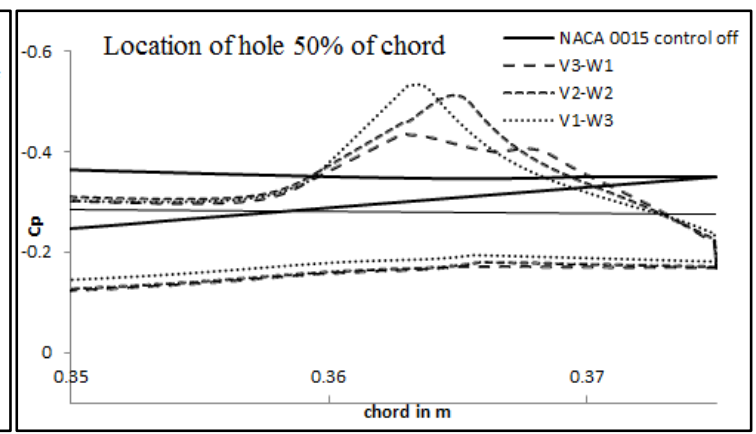

(f)

Fig. 12: Pressure distribution over a baseline airfoil NACA 0015 with hybrid controller on and off cases, (a), (b), (c) are blowing and (d), (e), (f) are suction $(\mathrm{v} 1=17.5 \mathrm{~m} / \mathrm{s}, \mathrm{v} 2=35 \mathrm{~m} / \mathrm{s}, \mathrm{v} 3=52.5 \mathrm{~m} / \mathrm{s}, \mathrm{w} 1=0.0015 \mathrm{~m}, \mathrm{w} 2=0.002$, and $\mathrm{w} 3=0.0025)$ 
The influence of each and every parameter is analyzed in detail. The $\mathrm{L}_{9}$ orthogonal array and aerodynamic characteristic of an airfoil for nine experiments is shown in Table 3 and Table 4. All the experiments show the improvement in aerodynamic characteristics. Figure 13 shows the variation of parameters against means of mean and the parameter with a higher value of mean has a more significant influence on lift to drag ratio (L/D ratio).

Table 3: L9 Orthogonal array-blowing

\begin{tabular}{|c|c|c|c|c|c|c|c|c|c|}
\hline \multirow{3}{*}{ S.No } & \multirow{3}{*}{$\begin{array}{l}\text { Velocity } \\
\text { in }[\mathbf{m} / \mathbf{s}]\end{array}$} & \multirow{3}{*}{$\begin{array}{l}\text { Position of } \\
\text { slot in \% } \\
\text { of c }\end{array}$} & \multirow{3}{*}{$\begin{array}{c}\text { Size of } \\
\text { slot in } \\
{[\mathrm{m}]}\end{array}$} & \multicolumn{6}{|c|}{ Blowing aerodynamic coefficients } \\
\hline & & & & \multicolumn{2}{|c|}{ Active } & \multicolumn{4}{|c|}{ Hybrid } \\
\hline & & & & $\mathrm{C}_{\mathrm{l}}$ & $\mathbf{C}_{d}$ & L/D & $\mathrm{C}_{1}$ & $\mathbf{C}_{d}$ & L/D \\
\hline 1 & 17.5 & 10 & 0.0015 & 0.87 & 0.225 & 3.9 & 0.887 & 0.205 & 4.3 \\
\hline 2 & 17.5 & 30 & 0.002 & 1.03 & 0.181 & 5.7 & 1.02 & 0.158 & 6.5 \\
\hline 3 & 17.5 & 50 & 0.0025 & 1.01 & 0.1974 & 5.1 & 0.977 & 0.1717 & 5.7 \\
\hline 4 & 35 & 30 & 0.0015 & 1.14 & 0.161 & 7.1 & 1.156 & 0.133 & 8.7 \\
\hline 5 & 35 & 50 & 0.002 & 1.11 & 1.84 & 0.6 & 1.043 & 0.1607 & 6.5 \\
\hline 6 & 35 & 10 & 0.0025 & 1.08 & 0.133 & 8.1 & 1.18 & 0.0953 & 12.4 \\
\hline 7 & 52.5 & 50 & 0.0015 & 1.211 & 0.181 & 6.7 & 1.127 & 0.15 & 7.5 \\
\hline 8 & 52.5 & 10 & 0.002 & 1.4 & 0.1 & 14.0 & 1.52 & 0.0657 & 23.1 \\
\hline 9 & 52.5 & 30 & 0.0025 & 1.29 & 0.143 & 9.0 & 1.32 & 0.12 & 11.0 \\
\hline
\end{tabular}

Table 4: L9 Orthogonal array-suction

\begin{tabular}{lcccccccccc}
\hline S.No & $\begin{array}{c}\text { Velocity } \\
\text { in [m/s] }\end{array}$ & $\begin{array}{c}\text { Position of } \\
\text { slot in \% } \\
\text { of c }\end{array}$ & $\begin{array}{c}\text { Size of } \\
\text { slot in } \\
{[\mathbf{m}]}\end{array}$ & \multicolumn{4}{c}{ Suction aerodynamic coefficients } \\
& & $\mathbf{C}_{\mathbf{l}}$ & $\mathbf{C}_{\mathbf{d}}$ & $\mathbf{L} / \mathbf{D}$ & $\mathbf{C}_{\mathbf{l}}$ & $\mathbf{C}_{\mathbf{d}}$ & $\mathbf{L} / \mathbf{D}$ \\
\hline $\mathbf{1}$ & 17.5 & 10 & 0.0015 & 1.19 & 0.135 & 8.81 & 1.17 & 0.108 & 10.8 \\
$\mathbf{2}$ & 17.5 & 30 & 0.002 & 1.13 & 0.172 & 6.57 & 1.06 & 0.152 & 7.0 \\
$\mathbf{3}$ & 17.5 & 50 & 0.0025 & 1.023 & 0.202 & 5.06 & 1.02 & 0.182 & 5.6 \\
$\mathbf{4}$ & 35 & 30 & 0.0015 & 1.19 & 0.161 & 7.39 & 1.147 & 0.133 & 8.6 \\
$\mathbf{5}$ & 35 & 50 & 0.002 & 1.09 & 0.198 & 5.51 & 1.084 & 0.191 & 5.7 \\
$\mathbf{6}$ & 35 & 10 & 0.0025 & 1.48 & 0.069 & 21.45 & 1.49 & 0.0424 & 35.1 \\
$\mathbf{7}$ & 52.5 & 50 & 0.0015 & 1.11 & 0.198 & 5.61 & 1.09 & 0.191 & 5.7 \\
$\mathbf{8}$ & 52.5 & 10 & 0.002 & 1.55 & 0.061 & 25.41 & 1.54 & 0.033 & 46.7 \\
$\mathbf{9}$ & 52.5 & 30 & 0.0025 & 1.36 & 0.132 & 10.30 & 1.34 & 0.1109 & 12.1 \\
\hline
\end{tabular}

First, the influence of velocity on mitigation of flow separation on a surface is taken as one of the primary parameters. The velocities of the jets considered are $0.5,1$, and 1.5 times of freestream velocity. Both, active and hybrid controllers with jet velocity of 52.5 $\mathrm{m} / \mathrm{s}$ shows a superior performance compared to other velocities, irrespective of other parameters. The jet velocity of $17.5 \mathrm{~m} / \mathrm{s}$ in the active and hybrid controllers leads to the increase in total performance, but with decreased $\mathrm{C}_{1}$ value in active/hybrid blowing as shown in Table. 3. For other cases, the $C_{1}$ value is increased and $C_{d}$ value is decreased. The performance of the system increases proportionally to the velocity of the jet, as shown in Fig. 13.

The width of the slot is taken as another parameter to study the controller effect. The slot sizes of $0.0015,0.002$, and $0.0025 \mathrm{~m}$ are considered. The slot of $0.002 \mathrm{~m}$ gives high 
aerodynamic performance with the combination of jet velocity of $52.5 \mathrm{~m} / \mathrm{s}$ and slot position of $10 \%$ of the chord in a blowing and suction case. As the slot size increases or decreases from the optimum value $(0.002 \mathrm{~m})$, the performance of the all controllers starts to decelerate, as shown in Fig. 13.

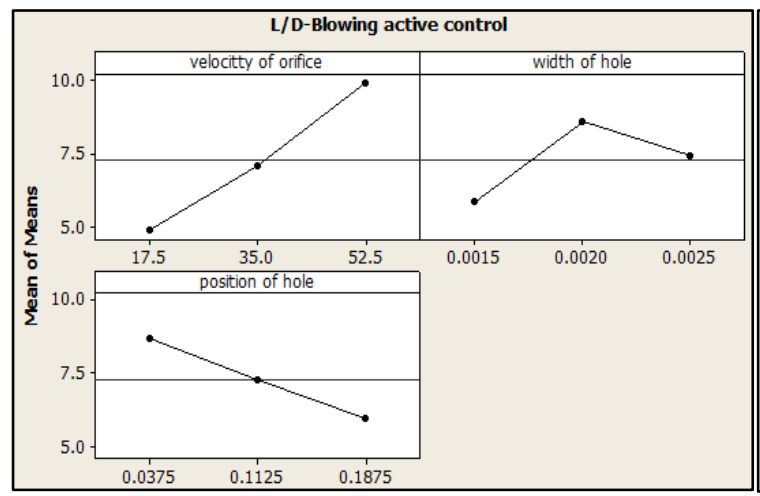

(a)

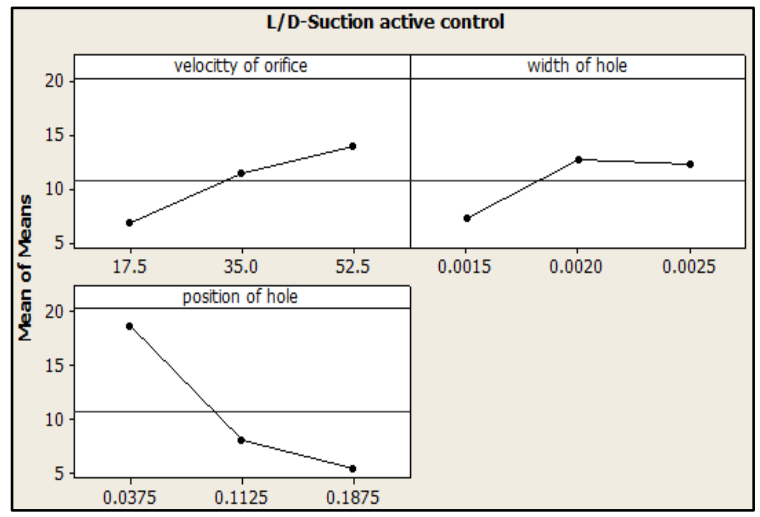

(c)

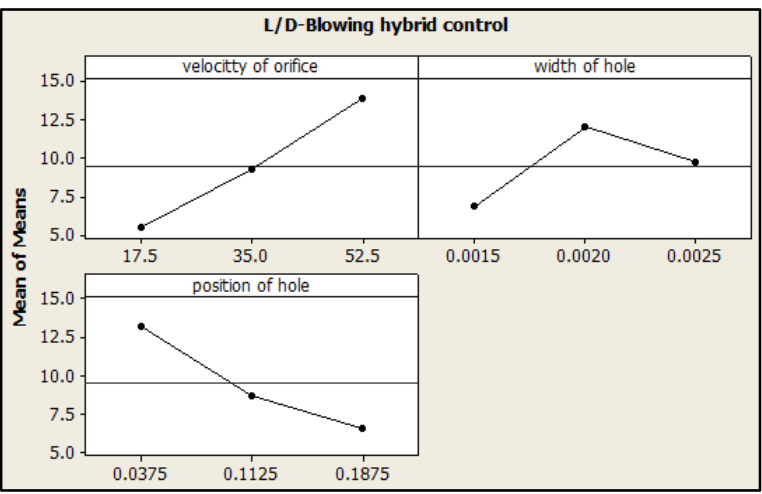

(b)

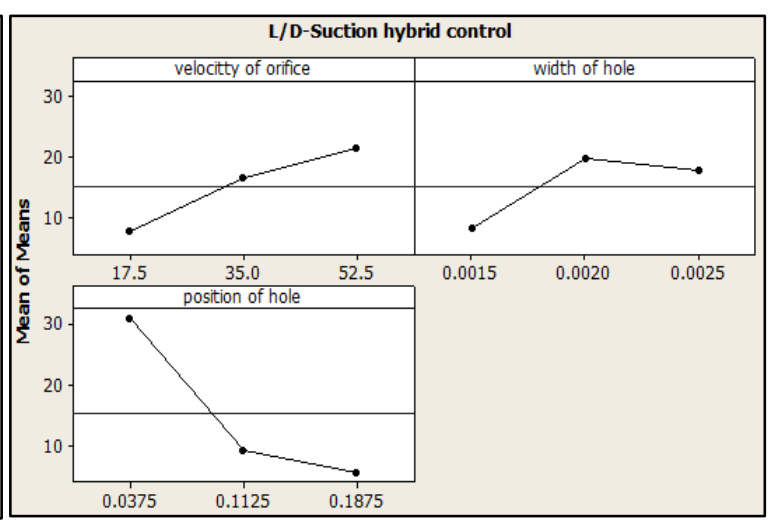

(d)

Fig. 13: Influence of parameters on active and hybrid control: (a), (b) are blowing active and hybrid, and (c), (d) are suction active and hybrid.

The other key parameter of the controller effectiveness is the position of the controller slot. The position of slot at $10 \%$ of chord with a size of $0.002 \mathrm{~m}$ gives good aerodynamic characteristics at high blowing/suction velocity. This is possible because the flow separation starts at $10 \%$ of chord. When the position of slot moved aft, the efficiency of a controller decreases even with a high jet velocity and a slot size of $0.002 \mathrm{~m}$, as shown in Fig. 13. The optimum combination of parameters for delaying or mitigating the flow separation is the position of slot at $10 \%$ of chord with $0.002 \mathrm{~m}$ size, and jet velocity of $52.5 \mathrm{~m} / \mathrm{s}$.

The aerodynamic characteristics are also statistically analyzed by analysis of variance (ANOVA) to know the exact contribution of the parameters on the efficiency of the controllers. The output of ANOVA is given in Table 5, and it also shows that the velocity has a high significance in blowing and blowing hybrid controllers, followed by position of the slot. In suction and suction hybrid controllers the location of the slot has a significant influence, followed by the velocity parameter. The increase in L/D ratio through active and hybrid controllers (blowing/suction) are promising by delaying the flow separation over the suction side of the airfoil. 
Table 5: ANOVA output

\begin{tabular}{|c|c|c|c|c|c|c|}
\hline \multicolumn{7}{|c|}{ Analysis of Variance for L/D-blowing control, using Adjusted SS for Test } \\
\hline Source & DF & Seq SS & Adj SS & Adj MS & $\mathbf{F}$ & $\mathbf{P}$ \\
\hline Blowing velocity in $\mathbf{m} / \mathbf{s}$ & 2 & 37.815 & 37.815 & 18.907 & 3.86 & 0.206 \\
\hline width of hole in $\mathbf{m}$ & 2 & 10.987 & 10.987 & 5.494 & 1.12 & 0.471 \\
\hline Position of hole in \% of $\mathrm{C}$ & 2 & 11.053 & 11.053 & 5.527 & 1.13 & 0.47 \\
\hline Error & 2 & 9.801 & 9.801 & 4.901 & & \\
\hline \multicolumn{7}{|c|}{ Analysis of Variance for L/D-blowing hybrid control, using Adjusted SS for Test } \\
\hline Source & DF & Seq SS & Adj SS & Adj MS & $\mathbf{F}$ & $\mathbf{P}$ \\
\hline Blowing velocity in $\mathbf{m} / \mathbf{s}$ & 2 & 105.32 & 105.32 & 52.66 & 2.42 & 0.292 \\
\hline width of hole in $\mathbf{m}$ & 2 & 39.7 & 39.7 & 19.85 & 0.91 & 0.523 \\
\hline Position of hole in \% of $\mathrm{C}$ & 2 & 69.61 & 69.61 & 34.81 & 1.6 & 0.385 \\
\hline Error & 2 & 43.53 & 43.53 & 21.76 & & \\
\hline \multicolumn{7}{|c|}{ Analysis of Variance for L/D-suction control, using Adjusted SS for Test } \\
\hline Source & DF & Seq SS & Adj SS & Adj MS & $\mathbf{F}$ & $\mathbf{P}$ \\
\hline Suction velocity in $\mathbf{m} / \mathbf{s}$ & 2 & 78.03 & 78.03 & 39.02 & 2.43 & 0.292 \\
\hline width of hole in $\mathbf{m}$ & 2 & 53.89 & 53.89 & 26.94 & 1.68 & 0.373 \\
\hline Position of hole in \% of $\mathrm{C}$ & 2 & 297.11 & 297.11 & 148.55 & 9.25 & 0.098 \\
\hline Error & 2 & 32.11 & 32.11 & 16.06 & & \\
\hline \multicolumn{7}{|c|}{ Analysis of Variance for L/D-suction control, using Adjusted SS for Test } \\
\hline Source & DF & Seq SS & Adj SS & Adj MS & $\mathbf{F}$ & $\mathbf{P}$ \\
\hline Suction velocity in $\mathbf{m} / \mathbf{s}$ & 2 & 288.24 & 288.24 & 144.12 & 1.63 & 0.381 \\
\hline width of hole in $\mathbf{m}$ & 2 & 220.35 & 220.35 & 110.18 & 1.24 & 0.446 \\
\hline Position of hole in \% of $\mathrm{C}$ & 2 & 1128.29 & 1128.29 & 564.15 & 6.37 & 0.136 \\
\hline Error & 2 & 177.1 & 177.1 & 88.55 & & \\
\hline
\end{tabular}

The detailed analysis of the skin friction coefficient over a suction side in control off and on cases is carried out for velocity (blowing/suction) $52.5 \mathrm{~m} / \mathrm{s}$, slot width $0.002 \mathrm{~m}$, and position of slot of $10 \%$ of chord. In the blowing case, the momentum is added to energize the fluid particles to overcome the retardation by boundary layer effect. Figure 14 (a) shows the delay in the separation of flow over the suction side when blowing through the slot is carried out, and the skin friction increases in the blowing area. The separation point is located at $10 \%$ of the chord in the control off case and it is moved to $55 \%$ of chord from L.E in the control on case. The activation of the passive controller, along with blowing, leads to the movement of the separation point to $74 \%$ of chord and it is seen in Fig. 14(c). When the controller is activated with suction, the momentum is diffused with an increase in skin friction coefficient on the suction side and it is identified, as shown in Fig. 14(b), and the separation point is moved to $79 \%$ of chord. When the hybrid controller with suction is employed, the separation takes place at $80 \%$ of chord and it is shown in Fig. 9(d). 


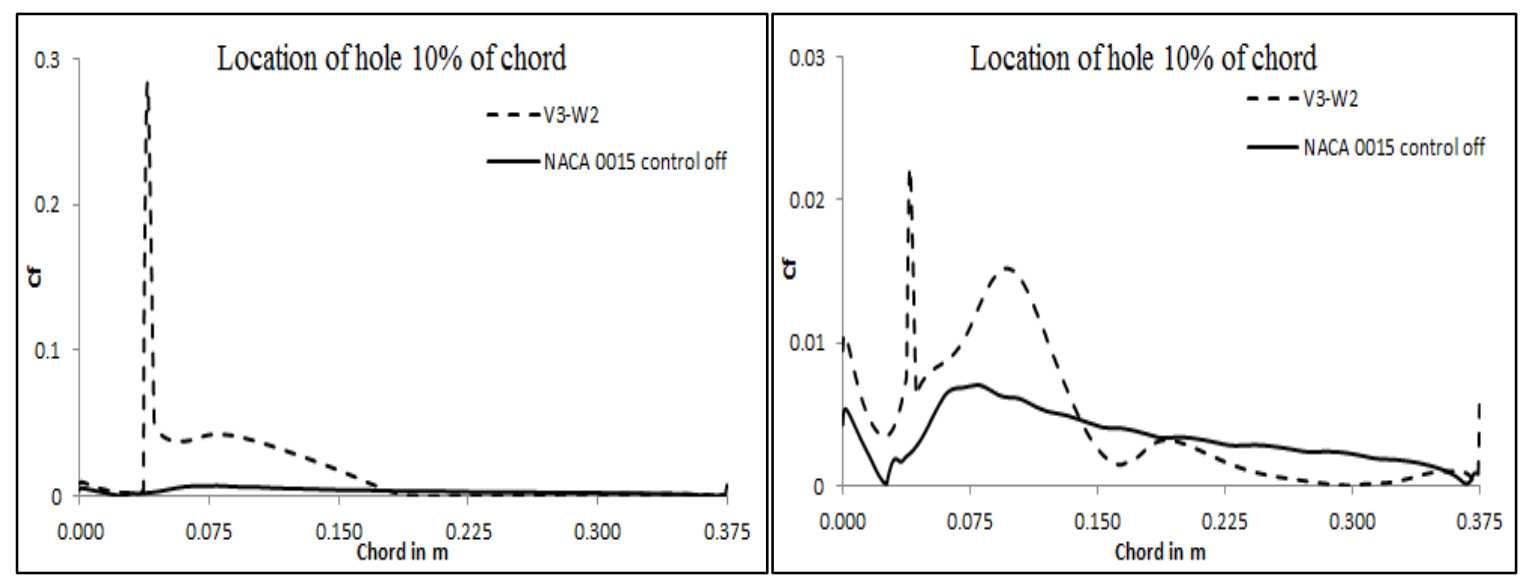

(a)

(b)

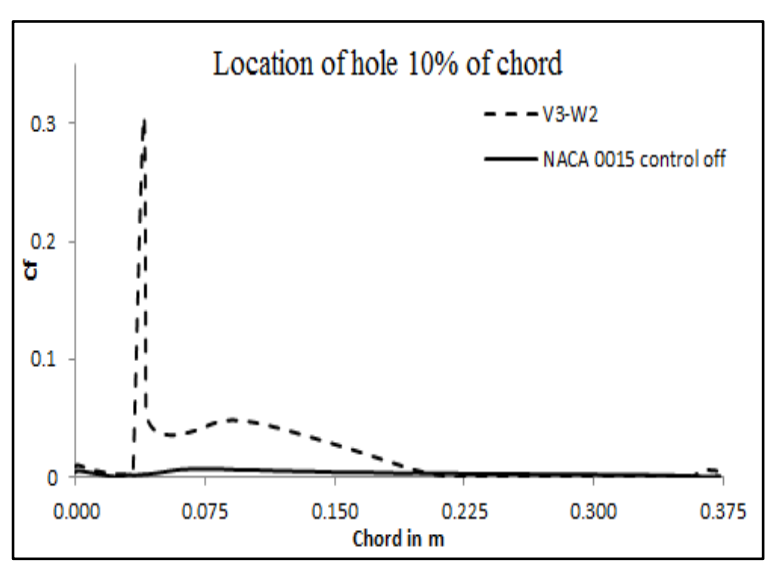

(c)

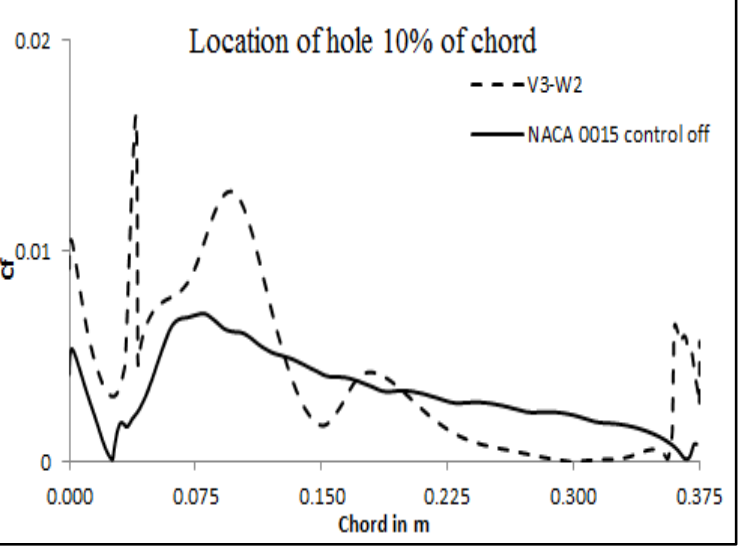

(d)

Fig. 14: Skin friction coefficient over the suction side: (a) blowing, (b) suction (c) hybrid with blowing and (d) hybrid with suction (v3 $=52.5 \mathrm{~m} . / \mathrm{s}$, and $\mathrm{w} 3=0.0025)$.

Figure 15 show the streamlines over the NACA 0015 airfoil with control. In airfoil with the control off case, the flow gets separated near L.E and when control (velocity (blowing/suction) $=52.5 \mathrm{~m} / \mathrm{s}$, hole width $0.002 \mathrm{~m}$, and position of hole is $10 \%$ chord ) is on the flow separation over an airfoil gets delayed is seen in Fig. 15. This shows the controller works effectively to delay the separation of flow over the suction side of an airfoil.

\subsection{Surrogate Model}

The GRNN and RBF are used as the surrogate models in this work. Inputs for the training sets are the blowing/suction velocity, width of the slot, and the position of the slot from the leading edge and the output variable is the $\mathrm{L} / \mathrm{D}$ ratio. The surrogate models are trained with training sets shown in Table 3 and 4, for the blowing and suction case separately. The training time is around 20 seconds and the convergence trend of the RBF model is shown in Fig. 16(a). Here, a spread constant is taken as one and a Matlab neural network toolbox is employed for training both networks. Fig. 16 (b) shows the outputs computed from GRNN against target values. 


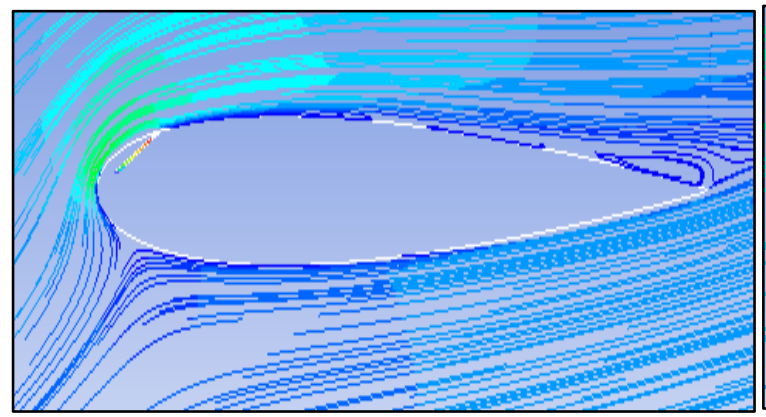

(a)

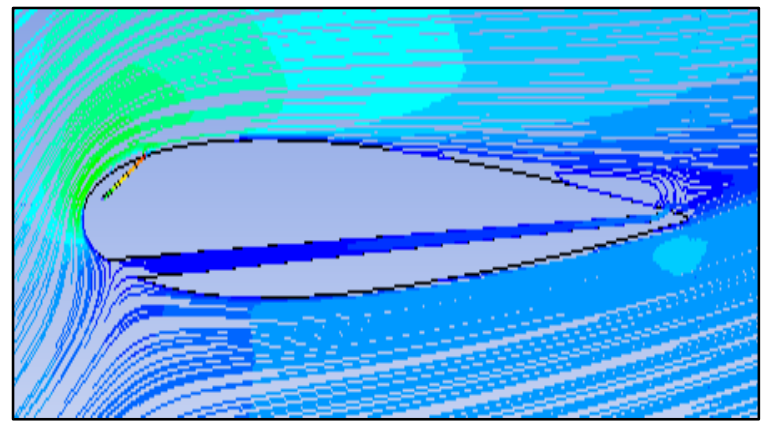

(c)

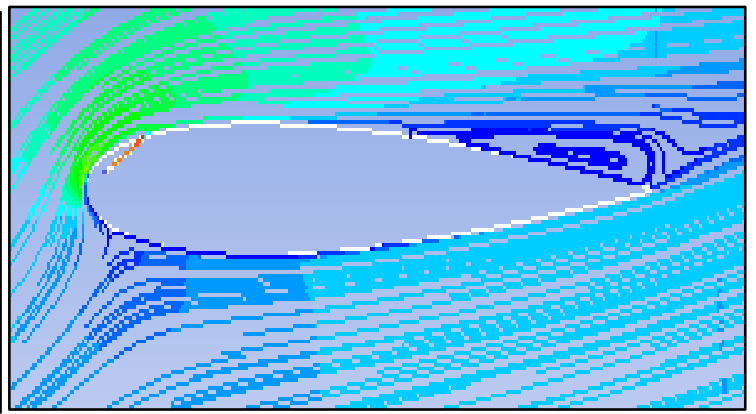

(b)

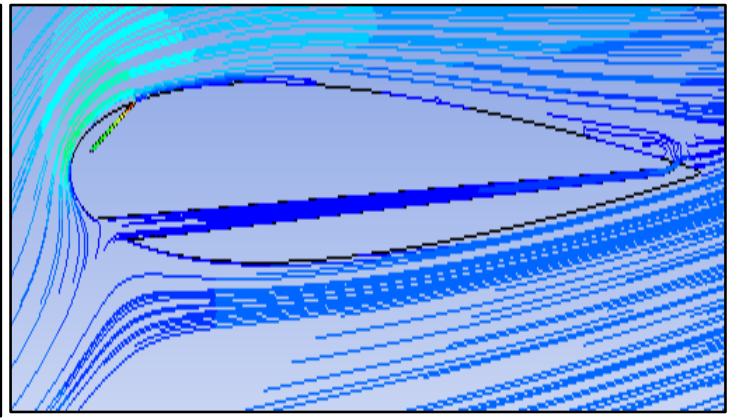

(d)

Fig. 15: Streamline flow over an airfoil: (a) blowing, (b) suction, (c) hybrid with blowing and (d) hybrid with suction.

The identified results are shown in Table 6, and they are in good agreement with those obtained from a conventional flow solver (ANSYS) outputs for a few test cases. Performance wise, both the surrogate models are similar and RBF has bagged the best performer in blowing operations in terms of training speed and accuracy. These models can be used to optimize the parameters of the controller without redesigning the airfoil model in the software front end and saves a lot of computational time.

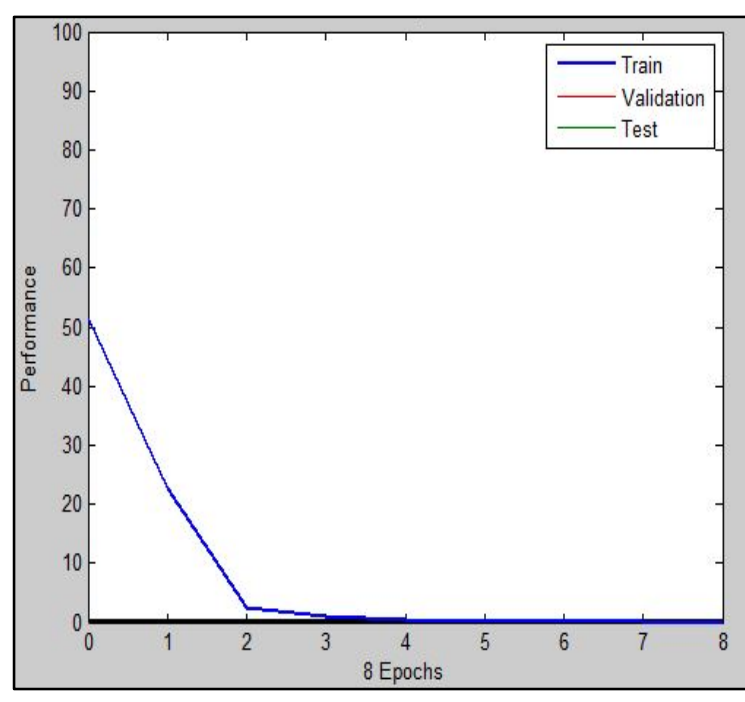

(a)

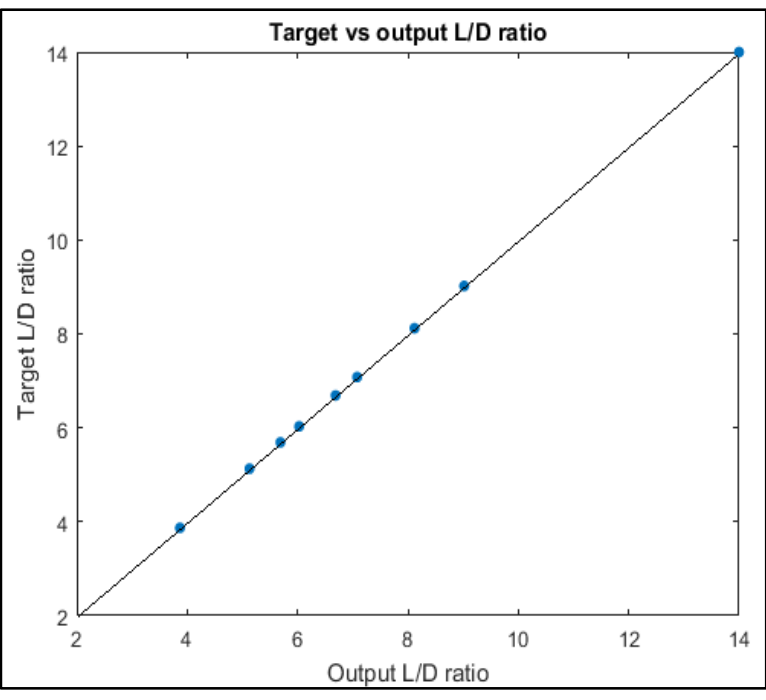

(b)

Fig. 16 (a) Convergence plot of RBF neural network, and (b) GRNN target versus output $\mathrm{L} / \mathrm{D}$ ratio. 
Table 6: validation of surrogate models

\begin{tabular}{|c|c|c|c|c|c|c|c|c|}
\hline \multirow{3}{*}{$\begin{array}{c}\text { Parameters } \\
\text { V=52.5 } \\
{[\mathrm{m} / \mathrm{s}]} \\
\text { Width }= \\
0.0015[\mathrm{~m}]\end{array}$} & \multicolumn{8}{|c|}{ L/D } \\
\hline & \multicolumn{4}{|c|}{ Blowing } & \multicolumn{4}{|c|}{ Suction } \\
\hline & RBF & Ansys & GRNN & Ansys & RBF & Ansys & GRNN & Ansys \\
\hline $\begin{array}{c}\text { Position= } \\
10 \% \text { of } \\
\text { chord }\end{array}$ & 14 & 14 & 13 & 14 & 25.83 & 21.42 & 25.83 & 21.42 \\
\hline
\end{tabular}

\section{CONCLUSIONS}

The parametric analysis of a controller to minimize/delay the flow separation effect was carried out with blowing and suction of an air jet over an airfoil section. The flow regime was considered to be incompressible with a Reynolds number of $8.96 \times 10^{5}$ and a chord length of the airfoil section of $0.375 \mathrm{~m}$. The airfoil aerodynamic characteristics were analyzed by a transitional k-kl- $\omega$ solver in ANSYS Fluent for the natural flow and then by employing active, and hybrid controllers. The hybrid controller comes with a combination of the active controller, which plays a role in delaying the flow separation and the passive controller to reduce the drag by increasing the static pressure upstream of the blowing slot, just ahead of trailing edge, over a suction surface. The active and hybrid controller efficiency were studied by varying the controller parameters including the blowing/suction velocity, slot width, and position of the slot. The number of experiments was reduced using a Taguchi design of experiments, and ANOVA was used to identify the most influencing parameters in performance of the controllers. The parametric study reveals that the velocity of the jet has more influence in comparison with the other two parameters in deciding the performance of blowing active and hybrid controllers. The position of the slot is found to be most influential in suction active and hybrid controllers. Finally, surrogate models based on RBF and GRNN were proposed to minimize the computational cost of a flow solver in understanding the effectiveness of the flow separation by varying the three controller parameters. The RBF outperforms in comparison with GRNN in all cases in predicting the $\mathrm{L} / \mathrm{D}$ ratio.

\section{REFERENCES}

[1] Currie IG. (2013) Fundamental mechanics of fluids, CRC Press, Boca Raton.

[2] Anderson JD. (2011) Fundamentals of Aerodynamics, McGRAW HILL, New York.

[3] Amitay M, Glezer A. (2002) Controlled transients of flow reattachment over stalled airfoils. Int J Heat Fluid Fl, 23(5):690-699.

[4] Duvigneau R, Visonneau M. (2003) Simulation and optimization of stall control for an airfoil with a synthetic jet. Aerosp Sci Technol, 10(4):279-287.

[5] Rumsey CL, Nishino T. (2011) Numerical study comparing RANS and LES approaches on a circulation control airfoil. Int J Heat Fluid Fl, 32(5):847-864.

[6] Azim R, Hasan MM, Ali M. (2015) Numerical investigation on the delay of boundary layer separation by suction for NACA 4412. Procedia Eng, 105:329-334.

[7] Ghadimi P, Rostami AB, Jafarkazemi F. (2012) Aerodynamic analysis of the boundary layer region of symmetric airfoils at ground proximity. Aerosp Sci Technol, 17(1):7-20.

[8] Favier J, Pinelli A, Piomelli U. (2012) Control of the separated flow around an airfoil using a wavy leading edge inspired by humpback whale flippers. Comptes Rendus Mécanique, 340(1-2):107-114. 
[9] Lin YF, Lam K, Zou L, Liu Y. (2013) Numerical study of flows past airfoils with wavy surfaces. J. Fluids Struct, 36:136-148.

[10] Faruqui SHA, Bari MAA, Emran M, Ahsan F. (2014) Numerical Analysis of Role of Bumpy Surface to Control the Flow Separation of an Airfoil. Procedia Eng, 90:255-260.

[11] Zhang W, Cheng W, Gao W, Ravi S. (2015) Geometrical effects on the airfoil flow separation and transition. Comput. Fluids, 116:60-73.

[12] Belamadi R, Djemili A, Ilinca A, Mdouki R. (2016) Aerodynamic performance analysis of slotted airfoils for application to wind turbine blades. J. Wind Eng. Ind. Aerodyn, 151:79-99.

[13] Fouatih OM, Medale M, Imrine O, Imine B. (2016) Design optimization of the aerodynamic passive flow control on NACA 4415 airfoil using vortex generators. Eur J Mech B-Fluid, 56:82-96.

[14] Eppler R. (1999) Airfoils with boundary layer suction, design and off-design cases. Aerosp. Sci. Technol, 3(7):403-415.

[15] Jiao Y, Lu Y. (2015) Parameter Optimization Research on Lift-enhancing of Multi-element Airfoil Using Air-blowing. Procedia Eng, 99:73-8.

[16] Zhao G, Zhao Q. (2014) Parametric analyses for synthetic jet control on separation and stall over rotor airfoil. Chin. J. Aeronaut, 27(5):1051-1061.

[17] Chapin VG, Benard E. (2015) Active control of a stalled airfoil through steady or unsteady actuation jets. J. Fluids Eng, 137(9): 091103.

[18] Gilarranz JL, Traub LW, Rediniotis OK. (2005) A new class of synthetic jet actuators-part II: application to flow separation control. J. Fluids Eng, 127(2):377-387.

[19] You D, Moin P. (2008) Active control of flow separation over an airfoil using synthetic jets application to flow separation control. J. Fluids Struct, 24(8):1349-1357.

[20] Tang H, Salunkhe P, Zheng Y, Du J, Wu Y. (2014) On the use of synthetic jet actuator arrays for active flow separation control. Exp. Therm. Fluid Sci, 57:1-10.

[21] Wang L, Li L, Fu S. (2014) Numerical Investigation of Active Flow Control on a Pitching NACA 0015 Airfoil Using Detached-eddy Simulation. Procedia Eng, 79:49-54.

[22] Hossain MA, Uddin MN, Islam MR, Mashud M: Enhancement of Aerodynamic Properties of an Airfoil by Co Flow Jet (CFJ) Flow. Am. J. Eng. Res 2015, 4: 103-112.

[23] Genc MS, Kaynak U. (2009) Control of laminar separation Bubble over a NACA 2415 aerofoil at low Re transitional flow using blowing/suction. In: $13^{\text {th }}$ International conference on Aerospace sciences and aviation technology: $26^{\text {th }}-28^{\text {th }}$ May, Egypt.

[24] Shi Y, Bai J, Hua J, Yang T. (2015) Numerical analysis and optimization of boundary layer suction on airfoils. Chin. J. Aeronaut, 28(2):357-367.

[25] Skarolek V, Karabelas J. (2016) Energy efficient active control of the flow past an aircraft wing: RANS and LES evaluation. Applied Mathematical Modelling, 40(2):700-725.

[26] Ali IS, Ahmed SS. (2011) Modelling of turbulent separation flow. World Academy of Science, Engineering and technology, 76:866-876.

[27] Kuwahara K, Surugadai S. (2000) Direct simulation of a flow around an airfoil. Available: http://www2.nagare.or.jp/jscfd/cfds14/pdf/b05-2.pdf.

[28] Guan X, Zhu Y, Song W. (2016) Application of RBF neural network improved by peak density function in intelligent color matching of wood dyeing. Chaos, Solitons \&Fractals, 89:485-490.

[29] Rooki R. (2016) Application of general regression neural network (GRNN) for indirect measuring pressure loss of Herschel-Bulkley drilling fluids in oil drilling. Measrurement, 85:184-191.

[30] Walters DK, Cokljat DA. (2008) Three-Equation Eddy-Viscosity Model for ReynoldsAveraged Navier-Stokes Simulations of Transitional Flow. J. Fluids Eng, 130(12):121401. 